\title{
FACTORS FROM UNDERWRITER THAT INFLUENCE INITIAL RETURN OF THE COMPANIES DOING INITIAL PUBLIC OFFERINGS IN INDONESIA STOCK EXCHANGE IN THE PERIOD OF 2004-2011
}

\author{
Ferry Sugianto \\ Alumnus of Investment Management Department, Faculty of Business and Economics, \\ Universitas Surabaya, \\ Ph.D. Student, Finance, National Chung Cheng University (CCU), Taiwan \\ Liliana Inggrit Wijaya \\ Lecturer of Investment Management Department, Faculty of Business and Economics, \\ Universitas Surabaya \\ e-mail: liliana_inggrit@yahoo.com
}

\begin{abstract}
The objective of this study is to examine whether the underwriter's factors affect the initial return of the companies that were going to do Initial Public Offerings (IPO). This study uses the quantitative approach using Ordinary Least Squares (OLS) method to examine whether the underwriter's factors affect the initial return. The samples of this study are companies which are doing the IPO in Indonesia Stock Exchange in the period of 2004- 2011. This study finds that the underwriter's factors have significant effect for the companies which do IPO, such as prestige, number of syndicate, experience, and oversubscription. But other independent variables like reputation, total assets, age, and price revision have no significant impact to initial return. The paper provides useful information for emitens how to choose good underwriters to avoid underpricing which causes wealth transfer to investors, the underwriters with good prestige, big syndicates, a lot of experiences, and less of doing oversubscription are recommended.
\end{abstract}

Keywords: stock, initial return, underwriter, emiten, Initial Public Offerings. 
Ferry Sugianto

Liliana Inggrit Wijaya
Jurnal Manajemen Bisnis Indonesia

Vol. 2, Nomor 1, Oct 2014

\section{INTRODUCTION}

In line with the economic growth, many companies are competing strictly to survive from the other competitors. Capital is the most important factor for the company to develop its business or to expand the enterprise. Capital can be used to build a new plant, run the new project, and develop the company's products so that the company can continue to withstand from the competition.

According to Emery (2007) there are two kinds of ways to raise the capital, there are borrowing to another party (debt financing) and issuing shares (equity financing). Debt has a negative side that must be considered by companies related to the company's fundamentals. The companies can be difficult to obtain funds compared with the infinity desire to expand. Therefore, issuing shares is more recommended for gaining funds massively from the public in the ease of raising capital in the future.The first thing to be done by a company in the issuance of shares can be called the Initial Public Offerings (IPO).

Changes in the status of the company into a public company (going public) intend to raise funds as much as possible, so the IPO price is expected high enough by the issuers. According to Ardiansyah (2004), on the pricing mechanism, the price difference in the primary market and the secondary market is usually happened because the price in the primary market is formed by an agreement between the issuer and underwriter (fair price), while price in the secondary market is determined by the market mechanism (demand and supply). If the IPO price (primary market) is lower than the market price (secondary market) occurred, there will be underpricing.

However, in Indonesia Stock Exchange, the original data on the primary and secondary markets is difficult to obtain, so in this research, it is analysed by using the initial returns. Apparently, the initial returns are collected from Indonesia Stock Exchange show that many shares prices are increasing on the first day and we can find from the calculations make the initial return positive, it can be called underpricing. The data of number of companies experiencing underpricing are shown in Table 1.

Table 1: Number of Companies Experiencing Underpricing on Average Trade Day-1 to Day-15 after IPO

\begin{tabular}{|c|c|c|c|c|}
\hline Year & $\begin{array}{l}\text { Companies } \\
\text { IPO }\end{array}$ & Doing & $\begin{array}{l}\text { Underpricing } \\
\text { Occurs }\end{array}$ & Percentage $(\%)$ \\
\hline 2004 & 12 & & 8 & 66,67 \\
\hline 2005 & 8 & & 5 & 62,50 \\
\hline 2006 & 12 & & 11 & 91,67 \\
\hline 2007 & 22 & & 16 & 72,73 \\
\hline 2008 & 18 & & 14 & 77,78 \\
\hline 2009 & 13 & & 5 & 38,46 \\
\hline 2010 & 21 & & 18 & 85,71 \\
\hline 2011 & 25 & & 16 & 64,00 \\
\hline Total & 131 & & 93 & 69,94 \\
\hline
\end{tabular}

Source: Indonesia Stock Exchange, processed 
Many companies experiencing underpricing are because various factors, according to Durukan (2002), there are several factors affecting underpricing in IPOs that resulted in various hypotheses, such as:

1. The winner's curse hypothesis. Beatty and Ritter (1986) and Rock (1986) in Durukan (2002) state that the investors take benefit from the IPO underpricing in purchasing shares and disclosure of private information.

2. The certification hypothesis. Booth and Smith (1986), Beatty (1989), Gale and Stinglitz (1989), Carter and Manaster (1990) in Durukan (2002) state that investment bankers and auditors must have the certification to reduce uncertainty in the IPO process, which can enhance the reputation of underwriter.

3. The signaling hypothesis. Allen and Faulhaber (1989), Grinblatt and Huang (1989), and Welch (1989) in Durukan (2002) state underpricing is a tool for signaling its quality, so it can obtain the return on the next offering.

4. The market feedback hypothesis. Jegadeesh et al. (1993) in Durukan (2002) states that the underwriter will make underpricing to induce regular investors by revealing information during the period prior to the IPO.

5. The lawsuit avoidance hypothesis. Tinic (1988) in Durukan (2002) states that underpricing in IPO is needed to reduce the possibility of prosecution lawsuits by investors.

6. The fads (impresario) hypothesis. Aggarwal and Rivoli (1990) and Ritter (1991) in Durukan (2002) suggest that abnormal initial return is not because of systematic underpricing, but it is because of overvaluation by investors or the mode in the early aftermarket trading.

Kenourgios (2007) also adds some points in the hypotheses that affect IPO underpricing, they are:

1. Monopsony power of underwriters hypothesis. Ritter (1984) argues that the investment banker will take advantage of the knowledge of the market conditions to underprice the offerings, to maximize the revenue.

2. Hypothesis of prestigious underwriters. Beatty and Ritter (1986) reveal that the underwriters care about their reputation and won't do too much underpricing in IPOs.

3. Market bandwagon hypothesis. Welch (1992) reveals that potential investors are not only concerned with the new offerings' informations, but also other investors. So, underwriters will do underpricing that can attract potential investors at the first-time.

4. Ownership or control dispersion hypothesis. Brennan and Franks (1997) suggest that underpricing can reduce the risk of a hostile takeover. Giving the stock largely to one party can increase the liquidity of the market and the number of small shareholders.

Several hypotheses reveal that the underwriter is the most widely affect the determination of the company's stock price, especially on the certification hypothesis, the market feedback hypothesis, the lawsuit avoidance hypothesis, underwriter monopsony power of hypothesis, hypothesis of prestigious underwriters, market bandwagon hypothesis, or control and ownership dispersion hypothesis. This is because the underwriters have more information so they can use nescience's issuers to minimize risk (Hanafi and Husnan, 1991). Asymmetry of information between the underwriter and the issuer makes many IPO prices underpricing. Underpricing can make wealth transfer issuers to investors (Beatty, 1989) so the corporate objectives can't be achieved fully. 
Many researches about the factors that influence the intitial return of the company has been reviewed in previous studies. They used the common factors or underwriter's factors specifically discussed. Common factors were investigated by many researchers. Yasa (2002), Triani (2006), and Sembel (2008) state that underwriter reputation has the positive effect on initial returns. However, the different results (negative effect) found by Ardiansyah (2004), Hidayah (2007), and Yunita (2010). Significance levels were different too, from the six studies, only 2 studies from Yasa (2002) and Hidayah (2007) which say significant effect of underwriter reputation is not significant to the initial return. Two existing research abroad, such as Durukan (2002) and Kim (2008), they state that the underwriter factors have no significant effect on initial returns. Moreover, in her research, Yunita (2010) concludes that the equation models using the common factors (such as issuer, underwriter reputation, and the reputation of the auditor) only explain a small fraction (less than 20\%), so there are more than $80 \%$ from other variables that influence initial returns.

The following researches focus on the underwriters factors because seven of the ten hypotheses indicating the underwriter factors are more dominant. Variables are taken differently, so they shows the different results. Guner (2000) and Jones (2010) state that the underwriter factors are negative significant on initial return, supported by two other studies of Kenourgios (2007) and Sharma (2010) with prestige variable, and also by Fung (2008) that states that the underwriter ranking effects negatively. However, two other studies found that underwriter factors have no significant effect on initial return, proposed by Almeida (2011) and $\mathrm{Su}(2011)$.

So, it is required a further study on the underwriter factors affecting the initial return, not only by underwriter reputation, but also by taking many factors from the previous studies. The factors are the underwriter's reputation, prestige of the underwriter, underwriter total assets, number of syndication, underwriter's age, underwriter's experience, price revision, and oversubscription.

\section{LITERATURE REVIEW}

The process of the company which offers shares to the public for the first time is called IPO (Initial Public Offering). Company's decision for going public must do with some calculations because the IPO firms are faced with some consequences, both beneficial (benefits) and adverse (costs) (Emery, 2007). Underwriters have roles to promote the companies' shares and to protect the public interest by providing information regarding the financial material and other information about the companies (Usman, 1991). Decision in the selection of underwriters is very important to consider the funding will be smoothly or otherwise, so it is needed to choose the professional underwriters (Sitompul, 1996). So, it can avoid underpricing in IPO.

Underpricing can be calculated by initial return. Initial return is a benefit that can be taken by shareholders because of the difference in price of shares purchased in the primary market (IPO) with the selling price in the first day on the secondary market (Daljono, 2000). To calculate Initial Return, we can use this formula:

$$
I R=\frac{P t_{1}-P t_{0}}{P t_{0}}
$$

whereas: 
Ferry Sugianto

Liliana Inggrit Wijaya
Jurnal Manajemen Bisnis Indonesia Vol. 2, Nomor 1, Oct 2014

$\mathrm{Pt}_{0}=\mathrm{IPO}$ price (offering price)

$\mathrm{Pt}_{1}=$ closing price (closing price) on the first day of IPO

The underwriter's factors that influence initial return are:

1. Underwriter's reputation. Underwriter is a party that has a lot of informations about the capital market (Yasa, 2002). Underwriter reputation can be used as a signal to reduce the level of uncertainty that is difficult to express through the prospectus and other information (Beatty, 1989). Various studies have been conducted in reputation variables, but the results were varies. There are several studies that support the theory, which is shown in the studies conducted by Hidayah (2007) and Jones (2010), they find that underwriter's reputation is negative significant on initial return. Another study that refutes this hypothesis is the research from Yasa (2002) which states that the reputation gives positive significant effect on initial return.

H1: Suspected that underwriter's reputation affects negatively to initial return on IPO in the period of 2004-2011.

2. Underwriter's prestige from capital raised. Capital raised is associated with prestige which can reduce underpricing in the IPO. According to Klein (2001) underwriter is usually compensated by a commission which is a fixed percentage of the capital raised to minimize underpricing, so the capital raised reflects the compensation paid to the underwriters and may also reflect the underwriter's prestige (Ardiansyah, 2004). According to Kenourgios (2007), underwriter prestige can be a proxy using the ratio of capital which has been enhanced through the IPO process, so prestige can be measured by using the capital raised (CR) with this formula:

$$
\text { prestige }=\frac{C R_{j}}{\sum_{i=1}^{n} C R_{\bar{k}}}
$$

whereas:

$\mathrm{CR}_{\mathrm{j}}=$ capital raised by each underwriter

$\mathrm{CR}_{\mathrm{i}}=$ capital raised by all underwriters

The result is the prestige affects negative significant to underpricing that occurs (Kenourgios, 2007).

H2: Suspected that underwriter's prestige affects negatively to initial return on IPO in the period of 2004-2011.

3. Total assets of underwriter. Assets according to the IASB (2006) is the possibility of future economic benefits obtained or controlled by an entity as a result of past transactions or events. Total assets represent the size of a company, the greater company's assets mean the greater size and prospect of the company in the future. According to Ardiansyah (2004) the larger companies have the greater certainty so that it will reduce uncertainty in future projects. According to Jones (2010) assets affect negatively to initial returns.

H3: Suspected that total assets of underwriter affect negatively to initial return on IPO in the period of 2004-2011.

4. Number of syndicates. Number of syndicates defined by Sharma (2010) as the number of investment banks in the syndicates, syndicates are chosen to avoid the wealth transfer from investors to issuers. Sharma (2010) also said that the number of syndicates affect positively on prestige, supported by Fung (2008) which states that the size of syndicates 
influence positively on experience. Whereas, prestige and experience have negative significant effects on initial return. Found by Hoberg (2007) that some investment banks does underpricing in the IPO market based on private information, the large number of syndicates will reduce the occurrence of this private information, so the large number of syndicates will cause reductions in the underpricing.

H4: Suspected that number of syndicates affects negatively to initial return on IPO in the period of 2004-2011.

5. Underwriter's age. According to Nurhidayati and Indriantoro (1998), firm's age shows how long the company can survive and shows that the company is able to compete in an industry. The longer life of the company means more information that can be provided by the company to the management itself. In line with the theory, Sharma (2010) reveals that age has negative significant effect on initial return.

H5: Suspected that underwriter's age affects negatively to initial return on IPO in the period of 2004-2011.

6. Underwriter's experience. Underwriter's experience shows the experience of managing IPO process and how to valuate performance of handled companies. According to Fung (2008), underwriter that has a lot of previous experience in IPO will have superior characteristics and more widely known than the underwriters doing few IPOs. This will be reflected in the number of IPOs that have been done by the underwriter, which many experiences in handling IPO make the risk become smaller.

H6: Suspected that underwriter's experience affects negatively to initial return on IPO in the period of 2004-2011.

7. Price revision. According to Keefe (2012), price revision is the percentage change from the expected offering price (the midpoint of the range on the filing date of the original filing) of the bid price. Price revision can be interpreted as the final bid price compared to the midpoint of the original price and minus one (Kim, 2008). Price revision can be calculated using the following formula:

$P R=\frac{\text { Final of fer price }}{\text { Ave (original filing price range) }}-1$

According to Jones (2010), price revision is providing the price dispersion that relies on information during the bookbuilding, specific IPO information, specific financial, and private information about the issuer known underwriter. According to Almeida (2011) and Kim (2008), price revision has positive effect on initial return.

H7: Suspected that price revision affects positively to initial return on IPO in the period of 2004-2011.

8. Oversubscription. Investment bank that has handled the IPO after issuing IPO can be oversubscribed, because no one beside underwriters really knows how accurate it reflects the interests of investors. Oversubscription should reflect investors' appetite in IPO by comparing the number of shares they want with the number of shares actually available. Oversubscription can be formulated by the following formula according to Kenourgios (2007):

Oversubscription $=\frac{\text { Demand Shares }}{\text { Offer Shares }}$ 
Kenourgios (2007) in his research examines the factors related to the company's initial returns, and the result is oversubscription has very positive significant correlation to stock returns.

H8: Suspected that oversubscription affects positively to initial return on IPO in the period of 2004-2011.

\section{RESEARCH METHOD AND DATA}

The study is a causal research because it explains the causal relationship between the variables in empirical model developed by researchers that is related to the influence of the variables affecting the initial return on a company doing IPO. Based on the approach, this research is a quantitative research/positivism that emphasizes the combination of deductive logic and the use of quantitative tools in interpreting a phenomenon objectively (Efferin, 2008).

There are two types of variables used in this study, namely dependent variables and independent variables. The dependent variable is the initial return of the companies doing IPO in Indonesia Stock Exchange in the period of 2004-2011. While, the independent variables are the underwriter's reputation, prestige of the underwriter, underwriter total assets, number of syndication, underwriter's age, underwriter's experience, price revision, and oversubscription.

Data used in this study is secondary data. Sources of data in this study are the financial statements and many informations of each company published in IDX Magazines, Indonesian Capital Market Directory, Investor Magazine, Yahoo Finance Website, IDX Website, NewsIDX Website, Ipot Indonesia Website, Kontan Website, Bisnis Website, Detik Finance Website, and Tempo Newsletter Website.

Data are processed with models used to analyze the causal relationship between the factors of underwriters with initial returns using Ordinary Least Squares (OLS) by Eviews 7. But there are some classic assumptions needed to run multiple regression, such as Normality, Multicollinearity, Autocorrelation, and Heteroscedasticity. And the regression equation used is as follows:

$\mathrm{IR}=\beta_{0}+\beta_{1} \mathrm{X}_{1}+\beta_{2} \mathrm{X}_{2}+\beta_{3} \mathrm{X}_{3}+\beta_{4} \mathrm{X}_{4}+\beta_{5} \mathrm{X}_{5}+\beta_{6} \mathrm{X}_{6}+\beta_{7} \mathrm{X}_{7}+\beta_{8} \mathrm{X}_{8}+\varepsilon$

Whereas:

IR = Initial Return

$\mathrm{X}_{1}=$ Underwriter's reputation

$\mathrm{X}_{2}=$ Prestige of underwriter

$\mathrm{X}_{3}=$ Underwriter's total assets

$\mathrm{X}_{4}=$ Number of syndications

$\mathrm{X}_{5}=$ Underwriter's age

$\mathrm{X}_{6}=$ Underwriter's experience

$\mathrm{X}_{7}=$ Price revision

$\mathrm{X}_{8}=$ Oversubscription

$\beta_{0}=$ The magnitude of the constant

$\beta_{\mathrm{i}}=$ regression coefficient

$\varepsilon=$ residual/error 
Ferry Sugianto

Liliana Inggrit Wijaya
Jurnal Manajemen Bisnis Indonesia

Vol. 2, Nomor 1, Oct 2014

And the hypotheses can be examined by t-test and F-test.

\section{RESULT AND DISCUSSION}

There are 118 shares of the company which are going to be analyzed. The number of samples must be fulfilled the minimum sample size requirement according to Tabachnick \& Fidell (1996). They suggested the number of samples must be conformed with this following formula: $\mathrm{N}>50+8 \mathrm{~m}$ (where $\mathrm{m}$ is the number of independent variables). If there are 8 independent variables, the minimum sample size is 114 . So, it means that 118 samples fulfilling the requirement. From the data which have been compiled, prestige $\left(\mathrm{X}_{2}\right)$, experience $\left(\mathrm{X}_{6}\right)$, price revision $\left(\mathrm{X}_{7}\right)$, and oversubscription $\left(\mathrm{X}_{8}\right)$ have mean numbers consecutively 0.48 ; 9.29; -0.04 ; and 3.82 . They also have standard deviations as $0.83 ; 11.86 ; 0.13$; and 3.99 whose the numbers more than $50 \%$ of their mean numbers. Total assets $\left(X_{3}\right)$, number of syndications $\left(\mathrm{X}_{4}\right)$, and age $\left(\mathrm{X}_{5}\right)$ have mean numbers as $11.67 ; 1.53$; and 16.86 but their standard deviations are less than $50 \%$ of the mean numbers, they are $0.49 ; 0.74$; and 7.17 . Reputations $\left(\mathrm{X}_{1}\right)$ has mean number 0.25 , that means a lot of companies work with badreputation underwriter. Others descriptive statistical numbers display on Table 2 and Table 3.

By using normality, multicollinearity, autocorrelation, and heteroscedasticity test, it is found that the data meet the assumptions of classical test. Therefore, multiple regressions using Ordinary Least Square (OLS) can be used. The classical test is explained as the following:

1. Normality test. This test can be shown by Probability Jarque Bera numbers. The result shows that the Probability Jarque Bera numbers in IR1 until IR15 are 0.00. Winarno (2009) argues that the normal distribution data needs Probability Jarque Bera number greater than 0.05. But, Gujarati (1995) also explains that some independent variables and identically random distributed, with little exception this data will be normally distributed.

2. Multicollinearity test. For detecting the problem of multicollinearity the regression model should be run first and we can use coefficient of determination as the indicator $\left(\mathrm{R}^{2}\right)$. Nachrowi (2006) says that coefficient of determination is high if it is more than $70 \%$. The $\mathrm{R}^{2}$ of data which obtained are less than $10.3 \%$. So, it means that there is no problem with multicollinearity.

3. Autocorrelation test. We use Durbin-Watson Test to examine there is autocorrelation problem or not. Nachrowi (2006) also argues that if the Durbin-Watson Stat is in DU until 4-DU interval (1.54 - 2.46), we can accept $\mathrm{H}_{0}$ meaning no autocorrelation problem. And the data shows that there is no autocorrelation problem happens.

4. Heteroscedasticity test. White Test is required to test the heteroscedasticity problem. If the Obs*R-squared $\alpha$ is less than $5 \%$, it concludes that the data is heteroscedastic. But, all results show the numbers more than $5 \%$, so there is no heteroscedasticity problem.

Table 4 displays the results of hypothesis testing, such as types of the relationship and the level of significance of the underwriter's factors on initial return. The variables that affect the initial return significantly is prestige $\left(\mathrm{X}_{2}\right)$ on the model IR3 which is negative significant impact with signification of less than $10 \%$, number of syndications $\left(\mathrm{X}_{4}\right)$ on the model IR1 is negative significant impact with a significance value of less than $10 \%$, oversubscription $\left(\mathrm{X}_{8}\right)$ in the model IR1 has positive significant impact with a significance value of less than $1 \%$, and the experience $\left(\mathrm{X}_{6}\right)$ on the model IR1 to IR15 has negative significant impact with significance level less than $1 \%$ for IR3 to IR10 and 5\% to the value of IR1, IR2, and IR11 to IR15. While, the other variables have no significant impact on initial returns. 
Apart from the Probability t-statictic, significance level of the models can be seen in Probability F-statistic. The F-statistic Probability values less than 5\% of the overall equation model can be said that it is significant. In the model equations obtained. IR1 to IR15 has Probability F-statistic greater than $10 \%$, except in the IR1 with value less tha $1 \%$. This suggests that the best model is IR1.

\section{CONCLUSION}

This study finds that the underwriter's factors have significant effect for the companies which are doing IPO, such as prestige, number of syndicate, experience, and oversubscription. But other independent variabels like reputation, total assets, age, and price revision have no significant impact to initial return.

Capital raised is associated with prestige which can reduce underpricing in the IPO. This in line with our finding that prestige has negative significant effect to initial return. And according to Klein (2001) underwriter is usually compensated by a commission which is a fixed percentage of the capital raised to minimize underpricing (low initial return). Another independent variable is number of syndicates. The result shows that this variable has negative significant effect to initial return in line with the previous research by Sharma (2010), Fung (2008), and Hoberg (2007). Sharma (2010) argues that syndicates are chosen to avoid the wealth transfer from investors to issuers so number of syndicates affect positively on prestige, supported by Fung (2008) which states that the size of syndicates influence positively on experience. Whereas, prestige and experience have negative significant effects on initial return. Hoberg (2007) also strengthen this argumentations, the large number of syndicates will reduce the occurrence of this private information, so the large number of syndicates will cause reductions in the underpricing. Another variable that shows negative significant effect is underwriter's experience, this argumentation is supported by Fung (2008) who argues that underwriter that has a lot of previous experience in IPO will have superior characteristics and more widely known than the underwriters doing few IPOs. Different with other three independent variables, oversubscription has positive significant impact to initial retun. This result is same with the result that is gotten by Kenourgios (2007) which argues that oversubscription has very positive significant correlation to stock returns.

Other four variables have no signifacant impact to initial returns. Underwriter reputation result is not supporting previous findings from Hidayah (2007), Jones (2010), and Yasa (2002). It maybe caused by the different reference of reputable underwriter that we use. And Investor Magazine may not reflect the quality of underwriting from underwriter companies because it may just identify the short performance of underwriter. Total assets of underwriter and age also have no significant effect to initial return. These two variables is not strong enough to indicate the quality of a company. Big and old companies are not indicating that those companies is good in underwriting, for example Danatama (22 year-old company which just underwrote 7 companies) and UBS Securities Indonenesia (24 year-old company which just underwrote 1 company). Price revision also does not affect the initial return, so the previous results from Almeida (2011) and Kim (2008) are not proven in Indonesia Stock Exchange.

From this result, it can be known that initial returns can not only be described from one perspective, but there are a lot of factors affecting the initial return value. It is evidenced by the adjusted R-squared value that is only about $10.3 \%$ in Initial Return 1. Issuers should consider many factors and related parties, apart from his own company, such as 
underwriters, investors, auditors, regulatory, relation and many more. Therefore, for the further research, it is recommended to test the effects of other variables by connecting many of the factors with many parties, then look for the factors from which party that has the most significant impact on intial return.

\section{REFERENCES}

Aggarwal, R. and P. Rivoli, 1990, Fads in the Initial Public Offering Market?, Financial Management, 19:4, pp.45-57.

Allen, F. and G. Faulhaber, 1989, Signalling by Underpricing in the IPO Market, Journal of Financial Economics, 23:2, pp.303-323.

Almeida, Vinicio de Souza, 2011, Underwriter Reputation in Brazilian IPOs, Latin American Business Review, 12:4, pp. 255-280.

Ardiansyah, Misnen, 2004, Pengaruh Variabel Keuangan terhadap Return Awal dan Return 15 Hari setelah IPO di Bursa Efek Jakarta, Journal Riset Akuntansi Indonesia, Vol 7(2): 126-130.

Beatty, R.P. and J.R. Ritter, 1986, Investment Banking, Reputation, and the Underpricing of Initial Public Offerings, Journal of Financial Economics, 15:1, Issue 1, pp. 213-232.

Beatty, Randolph P, 1989, Auditor Reputation and the Pricing of Initial public Offering, Journal of Financial Economic, Vol.15.

Booth, J. and R. Smith, 1986, Capital Raising: Underwriting and the Certification Hypothesis, Journal of Financial Economics, 15, pp. 261-281.

Brennan, M., and Franks, J., 1997, Underpricing, Ownership, and Control in Initial Public Offerings of Equity Securities in the UK, Journal of Financial Economics, Vol. 45, pp. 391-413.

Carter, R. and S. Manaster, 1990, Initial Public Offerings and Underwriter Reputation, Journal of Finance, 45, pp.1045-1067.

Daljono, 2000, Analisis Faktor - Faktor Yang Mempengaruhi Initial Return Saham Yang Listing di BEJ Th 1990 - 1997, Simposium Nasional Akuntansi III, IAI: 556 - 571.

Durukan, M. Banu, 2002, The Relationship Between IPO returns and Factors Influencing IPO Performance: Case of Istanbul Stock Exchange, Managerial Finance, Vol. 28 Iss: 2 pp. 18-38.

Efferin, Sujoko, Stevanus Hadi Darmadji, dan Yuliawati Tan, 2008, Metode Penelitian Akuntansi: Mengungkap Fenomena dengan Pendekatan Kuantitatif dan Kualitatif, Graha Ilmu.

Emery, Douglas R., John D. Finnerty, dan John D. Stowe, 2007, Corporate Financial Management, 3rd Edition, Pearson Prentice Hall.

Emilia, L. Sulaiman, and R. Sembel, 2008, Faktor-faktor yang Mempengaruhi Initial Return 1 Hari, Return 1 Bulan, dan Pengaruh terhadap Return 1 Tahun Setelah IPO, Journal of Applied Finance and Accounting, Vol. 1 No. 1 November 2008, pp. 116-140.

Fung, Simon Yu Kit, Gul F. A., dan Radhakrishnan S., 2008, Investment Banks' Entry into New IPO Markets and IPO Underpricing, Available, http://www.ssrn.com.

Gale, I. and J. Stiglitz, 1989, The Information Content of Initial Public Offerings, Journal of Finance, 44, pp.469-477.

Grinblatt, M. and C.Y. Huang, 1989, Signalling and the Pricing of New Issues, Journal of Finance, 44, pp.393-420.

Gujarati, D.N. 2004. Basic Econometrics, $4^{\text {th }}$ ed. New York: Mc. Graw-Hill.

Guner, Nuray, Onder Z., dan Rhoades, S.D., 2000, Underwriter Reputation and Short-run IPO Returns: a Re-evaluation for an Emerging Market, The ISE Finance Awards Series, Vol. 1. 
Hanafi, M., dan Husnan, S., 1991, Perilaku Harga Saham di Pasar Perdana: Pengamatan di Bursa Efek Jakarta selama 1990, Management dan Usahawan Indonesia, November.

Hidayah, R., Firdaus, Rahayu R., dan Nita, D., 2007, Perbandingan Underpricing Saham Perdana Perusahaan Keuangan dan Non-keuangan di Bursa Efek Indonesia, Artikel Fakultas Ekonomi.

Hoberg, G., 2007, The Underwriter Persistence Phenomenon, Journal of Finance, 62(3): 1169-1206.

IASB, 2006, Information For Observers World Standard Setters Meeting, September 2006, London Agenda Paper 1a.

Jegadeesh, N., M. Weinstein, I. Welch, 1993, Initial Public Offerings and Subsequent Offerings, Journal of Financial Economics, 34, pp.153-175.

Joh, Sung Wook dan Kim, Yoo Hwan, 2011, Bookbuilding, Price Revision and Initial Returns of IPOs, SIRFE Working Paper Series.

Jones, Travis L., 2010, Endogenous Examination of Underwriter Reputation and IPO Returns, Managerial Finance, Vol. 36 Iss: 4 pp. 284-293.

Keefe, M.O., 2012, Does the Effect of Revealed Private Information on IPO First Trading Day Return differ by IPO Market Heat?, Available, http://ssrn.com/abstract=1324182.

Kenourgios, Dimitris F., 2007, Initial Performance of Greek IPOs, Underwriter's Reputation and Oversubscription, Managerial Finance, Vol. 33 Iss: 5 pp. 332-343.

Kim, Jaemin, Pukthuanthong-Le, dan Walker, 2008, Leverage and IPO Underpricing: Hi-tech versus Low-tech IPOs, Management Decision, Vol. 46, pp. 106-130.

Klein, Peter G. dan Zoeller K., 2001, Universal-Bank Underwriting and Conflicts of Interest: Evidence from German Initial Public Offerings, Preliminary Manuscript.

Nachrowi, D. dan Usman, H., 2006, Pendekatan Populer dan Praktis Ekonometrika untuk Analisis Ekonomi dan Keuangan, Lembaga Penerbit Fakultas Ekonomi Universitas Indonesia.

Nurhidayati, Siti dan Nur Indriantoro, 1998, Analisis Beberapa Faktor-faktor yang Berpengaruh terhadap Tingkat Underpriced pada Penawaran Perdana di Bursa Efek Jakarta, Jurnal Ekonomi dan Bisnis Indonesia, Vol. 13 No1.

Ritter, J., 1984, The Hot Issue Market of 1980, The Journal of Business, Vol. 57 No. 2, pp. 214-40.

Ritter, J., 1991, The Long-run Performance of Initial Public Offerings, Journal of Finance, 46:1, pp.3-27.

Ritter, J.R., 1998, Initial Public Offerings, Contemporary Finance Digest, 2:1,

Rock, K., 1986, Why New Issues are Underpriced?, Journal of Financial Economics, 15, pp.187-212.

Sharma, S.K. dan Seraphim, A., 2010, The Relationship Between IPO Underpricing Phenomenon \& the Underwriter's Reputation, The Romanian Economic Journal, no. 38.

Sitompul, Asril, 1996, Pasar Modal Penawaran Umum dan Permasalahannya, PT. Citra Aditya Bakti, Bandung.

Su, Chen dan Banggasa, K., 2011, Underpricing and Long Run Performance of Chinese IPOs: the Role of Underwriting Reputation, University of Liverpool Management School, UK.

Tabachnick, B. G., \& Fidell, L. S., 1996. Using Multivariate Statistics (5th ed.). New York: HarperCollins.Wilkinson, L., \& Task Force on Statistical Inference, APA Board of Scientific Affairs.

Tinic, S., 1988, Anatomy of Initial Public Offerings of Common Stock, Journal of Finance, 43, pp.789-822. 
Triani, Apriliani dan Nikmah, 2006, Reputasi Penjamin Emisi, Reputasi Auditor, Presentase Penjamin Emisi, Ukuran Perusahaan, dan Fenomena Underpricing: Studi Empiris pada Bursa Efek Jakarta, Simposium Nasional Akuntansi 9 Padang.

Usman, Marzuki, 1991, Promosi dan Informasi Pasar Modal Indonesia, Yayasan Mitra Dana.

Welch, I., 1989, Seasoned Offerings, Imitation Costs and the Underpricing of Initial Public Offerings, Journal of Finance, 44, pp.421-449.

Welch, I., 1992, Sequential Sales, Learning, and Cascades, Journal of Finance, Vol. 47, pp. 695-732.

Winarno, Wing Wahyu, 2009, Analisis Ekonometrika dan Statistika dengan Eviews, Edisi kedua, UPP STIM YKPN.

Yasa, Gerianta W., 2002, Penyebab Underpricing pada Penawaran Saham Perdana di Bursa Efek Jakarta, Universitas Udayana.

Yunita, Sandra, 2010, Pengaruh Informasi Keuangan dan Non Keuangan terhadap Initial Return pada Perusahaan yang Melakukan Initial Public Offering di BEI pada Periode 2001-2010, Tesis tidak dipublikasikan, Universitas Surabaya. 
Ferry Sugianto

Liliana Inggrit Wijaya
Jurnal Manajemen Bisnis Indonesia

Vol. 2, Nomor 1, Oct 2014

Tabel 2: Descriptive Statistic of Initial Return Day 1 until Day 15

\begin{tabular}{|c|c|c|c|c|c|c|c|c|c|c|c|c|c|c|c|}
\hline & 1 & & & & & IR6 & IR7 & IR8 & IR9 & & & & & & \\
\hline Me & $\begin{array}{c}0.23 \\
7840\end{array}$ & $\begin{array}{c}0.16 \\
4811\end{array}$ & \begin{tabular}{|c|}
0.13 \\
3044
\end{tabular} & $\begin{array}{r}0.13 \\
2130\end{array}$ & \begin{tabular}{|c|}
0.13 \\
1729
\end{tabular} & $\begin{array}{r}0.12 \\
1792\end{array}$ & $\begin{array}{r}0.10 \\
8640\end{array}$ & \begin{tabular}{|c|}
0.11 \\
3040
\end{tabular} & $\begin{array}{c}0.11 \\
5160\end{array}$ & $\begin{array}{c}0.11 \\
0240\end{array}$ & $\begin{array}{c}0.11 \\
0196\end{array}$ & $\begin{array}{r}0.11 \\
3199\end{array}$ & $\begin{array}{c}0.11 \\
7956\end{array}$ & \begin{tabular}{|c|}
0.11 \\
6531
\end{tabular} & $\begin{array}{l}0.11 \\
8186\end{array}$ \\
\hline & $\begin{array}{c}0.12 \\
4144\end{array}$ & $\begin{array}{c}0.11 \\
1821\end{array}$ & $\begin{array}{r}0.10 \\
5299\end{array}$ & $\begin{array}{l}0.11 \\
8314\end{array}$ & \begin{tabular}{|c|}
0.10 \\
1852
\end{tabular} & $\begin{array}{r}0.10 \\
4312\end{array}$ & $\begin{array}{r}0.10 \\
3807\end{array}$ & $\begin{array}{l}0.08 \\
6628\end{array}$ & \begin{tabular}{|c|}
0.09 \\
7694
\end{tabular} & $\begin{array}{r}0.09 \\
8490\end{array}$ & \begin{tabular}{|c|}
0.10 \\
1274
\end{tabular} & $\begin{array}{r}0.10 \\
2574\end{array}$ & \begin{tabular}{|c|}
0.09 \\
8507
\end{tabular} & $\begin{array}{c}0.10 \\
0251\end{array}$ & 0.11 \\
\hline Max & $\begin{array}{r}1.73 \\
0769 \\
\end{array}$ & $\begin{array}{r}2.73 \\
0315\end{array}$ & $\begin{array}{c}0.84 \\
0909\end{array}$ & $\begin{array}{l}0.85 \\
8974\end{array}$ & $\begin{array}{c}0.90 \\
2857\end{array}$ & $\begin{array}{c}0.93 \\
6937 \\
\end{array}$ & $\begin{array}{r}0.81 \\
1710 \\
\end{array}$ & $\begin{array}{r}1.01 \\
1508 \\
\end{array}$ & $\begin{array}{r}0.96 \\
8951 \\
\end{array}$ & $\begin{array}{c}0.88 \\
9321 \\
\end{array}$ & $\begin{array}{r}0.77 \\
8185 \\
\end{array}$ & $\begin{array}{r}0.88 \\
3775 \\
\end{array}$ & $\begin{array}{r}0.83 \\
9797 \\
\end{array}$ & \begin{tabular}{|l|}
0.81 \\
3437
\end{tabular} & $\begin{array}{r}0.80 \\
6364 \\
\end{array}$ \\
\hline & 0.75 & & & & & & & & & & $\begin{array}{l}2.935 \\
714\end{array}$ & $\mid \begin{array}{l}2.971 \\
420\end{array}$ & 481 & 481 & 610 \\
\hline & \begin{tabular}{|c|}
4991 \\
0.34 \\
\end{tabular} & 0.49 & \begin{tabular}{|l|}
000 \\
0.43
\end{tabular} & $\begin{array}{l}407 \\
0.42\end{array}$ & \begin{tabular}{|l|}
000 \\
0.42
\end{tabular} & \begin{tabular}{|l|}
000 \\
0.42
\end{tabular} & \begin{tabular}{|c|}
483 \\
0.42 \\
172
\end{tabular} & $\begin{array}{l}000 \\
0.44\end{array}$ & \begin{tabular}{|c}
483 \\
0.43 \\
1577
\end{tabular} & \begin{tabular}{|l|}
714 \\
0.43 \\
\end{tabular} & \begin{tabular}{|l|}
714 \\
0.43 \\
\end{tabular} & \begin{tabular}{|l|}
429 \\
0.44
\end{tabular} & 0.44 & \begin{tabular}{|l|}
481 \\
0.44 \\
\end{tabular} & $\frac{519}{0.45}$ \\
\hline Std. & 7249 & 0029 & 9927 & 7259 & 3830 & 8484 & 5173 & 3740 & 1577 & 9861 & 4128 & 3384 & & Jo & \\
\hline & 98 & & 3.742 & 23.472 & 978 & 2.915 & 3.071 & 804 & 410 & 3.001 & 593 & 3.019 & 786 & & 327 \\
\hline ur & & & & $\begin{array}{r}26.3 \\
8634 \\
\end{array}$ & $\begin{array}{l}21.2 \\
4635\end{array}$ & $\begin{array}{r}20.2 \\
5912 \\
\end{array}$ & & $\begin{array}{l}19.7 \\
7915 \\
\end{array}$ & $\begin{array}{r}20.2 \\
2968 \\
\end{array}$ & $\begin{array}{r}21.1 \\
3863 \\
\end{array}$ & \begin{tabular}{|c|}
22.1 \\
1921 \\
\end{tabular} & $\begin{array}{r}21.4 \\
5723 \\
\end{array}$ & $\begin{array}{r}23.7 \\
5208 \\
\end{array}$ & $\begin{array}{r}24.1 \\
5892 \\
\end{array}$ & $\begin{array}{r}24.3 \\
3660 \\
\end{array}$ \\
\hline & $\begin{array}{l}66.2 \\
6056 \\
\end{array}$ & $\begin{array}{l}2315 \\
612\end{array}$ & $\begin{array}{l}3737 \\
.587 \\
\end{array}$ & $\begin{array}{l}2926 \\
223\end{array}$ & & $\begin{array}{l}1631 \\
.729\end{array}$ & $\begin{array}{l}1821 \\
.865\end{array}$ & $\begin{array}{l}1538 \\
.875\end{array}$ & \begin{tabular}{l|l}
8 & 1626 \\
.501
\end{tabular} & $\begin{array}{l}1794 \\
.798\end{array}$ & $\begin{array}{l}1989 \\
.635\end{array}$ & $\begin{array}{l}1854 \\
.240\end{array}$ & $\begin{array}{l}2324 \\
293\end{array}$ & $\begin{array}{l}2415 \\
.737\end{array}$ & \\
\hline Proba & $\begin{array}{r}0.00 \\
0000 \\
\end{array}$ & $\begin{array}{r}0.00 \\
0000 \\
\end{array}$ & $\begin{array}{r}0.00 \\
0000\end{array}$ & $\begin{array}{r}0.00 \\
0000\end{array}$ & $\begin{array}{l}0.00 \\
0000\end{array}$ & $\begin{array}{r}0.00 \\
0000 \\
\end{array}$ & $\begin{array}{r}0.00 \\
0000 \\
\end{array}$ & $\begin{array}{c}0.00 \\
0000\end{array}$ & $\begin{array}{c}0.00 \\
0000 \\
\end{array}$ & $\begin{array}{r}0.00 \\
0000\end{array}$ & $\begin{array}{c}0.00 \\
0000 \\
\end{array}$ & $\begin{array}{r}0.00 \\
0000\end{array}$ & $\begin{array}{c}0.00 \\
0000\end{array}$ & $\begin{array}{c}0.00 \\
0000\end{array}$ & $\begin{array}{r}0.00 \\
0000\end{array}$ \\
\hline Sum & $\begin{array}{r}28.0 \\
6512 \\
\end{array}$ & $\begin{array}{r}19.4 \\
4773 \\
\end{array}$ & $\begin{array}{r}15.6 \\
9921 \\
\end{array}$ & $\begin{array}{r}15.5 \\
9138 \\
\end{array}$ & $\begin{array}{r}15.5 \\
4406 \\
\end{array}$ & $\begin{array}{r}14.3 \\
7151 \\
\end{array}$ & $\begin{array}{r}12.8 \\
1948 \\
\end{array}$ & $\begin{array}{r}13.3 \\
3870 \\
\end{array}$ & $\begin{array}{l}13.5 \\
8882 \\
\end{array}$ & $\begin{array}{r}13.0 \\
0830\end{array}$ & $\begin{array}{r}13.0 \\
0316\end{array}$ & $\begin{array}{r}13.3 \\
5744 \\
\end{array}$ & $\begin{array}{r}13.9 \\
1878 \\
\end{array}$ & $\begin{array}{r}13.7 \\
5068 \\
\end{array}$ & $\begin{array}{r}13.9 \\
4598 \\
\end{array}$ \\
\hline & 14.1 & 28.0 & 22.6 & 21.3 & 21.0 & 21.4 & 21.1 & 23.0 & 21.7 & 22.6 & 22.0 & 23.0 & 23.4 & 23.2 & 23.7 \\
\hline ev. & 0805 & 9506 & 4373 & 5841 & 1690 & 8107 & 5029 & 3788 & 9224 & 3685 & 5065 & 0093 & 1614 & 0921 & 2181 \\
\hline atcons & 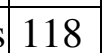 & 18 & 16 & 10 & 1 & 110 & 110 & 11 & 110 & 110 & 110 & 118 & 11 & 118 & 1 \\
\hline
\end{tabular}

Tabel 3: Descriptive Statistic of Independent Variables

\begin{tabular}{|l|l|l|l|l|l|l|l|l|}
\hline & $\mathrm{X} 1$ & $\mathrm{X} 2$ & $\mathrm{X} 3$ & $\mathrm{X} 4$ & $\mathrm{X} 5$ & $\mathrm{X} 6$ & $\mathrm{X} 7$ & $\mathrm{X} 8$ \\
\hline Mean & 0.254237 & 0.481461 & 11.67034 & 1.533898 & 16.86441 & 9.288136 & -0.042952 & 3.815714 \\
\hline Median & 0.000000 & 0.156854 & 11.60958 & 1.000000 & 18.00000 & 5.000000 & -0.018525 & 2.000000 \\
\hline Maximum & 1.000000 & 4.293456 & 12.46129 & 3.000000 & 35.00000 & 51.00000 & 0.250000 & 19.50000 \\
\hline Minimum & 0.000000 & 0.012445 & 10.43699 & 1.000000 & 2.000000 & 1.000000 & -0.616667 & 0.708000 \\
\hline Std. Dev. & 0.437288 & 0.829136 & 0.489531 & 0.735919 & 7.169398 & 11.86325 & 0.130184 & 3.985560 \\
\hline Skewness & 1.128823 & 2.642682 & -0.265512 & 0.981016 & -0.093342 & 2.273735 & -0.809053 & 1.970223 \\
\hline Kurtosis & 2.274242 & 9.775005 & 2.295860 & 2.520482 & 2.910290 & 7.686241 & 5.268273 & 6.548995 \\
\hline & & & & & & & & \\
\hline Jarque-Bera & 27.64983 & 363.0258 & 3.824184 & 20.05759 & 0.210919 & 209.6484 & 38.16971 & 138.2689 \\
\hline Probability & 0.000001 & 0.000000 & 0.147771 & 0.000044 & 0.899911 & 0.000000 & 0.000000 & 0.000000 \\
\hline & & & & & & & & \\
\hline Sum & 30.00000 & 56.81245 & 1377.100 & 181.0000 & 1990.000 & 1096.000 & -5.068320 & 450.2543 \\
\hline Sum Sq. Dev. & 22.37288 & 80.43356 & 28.03790 & 63.36441 & 6013.831 & 16466.20 & 1.982909 & 1858.509 \\
\hline & & & & & & & & \\
\hline Observations & 118 & 118 & 118 & 118 & 118 & 118 & 118 & 118 \\
\hline
\end{tabular}


Ferry Sugianto

Liliana Inggrit Wijaya
Jurnal Manajemen Bisnis Indonesia

Vol. 2, Nomor 1, Oct 2014

Tabel 4: Regression Results for Equation Models in Companies Doing IPO in the Period of 2004-2011

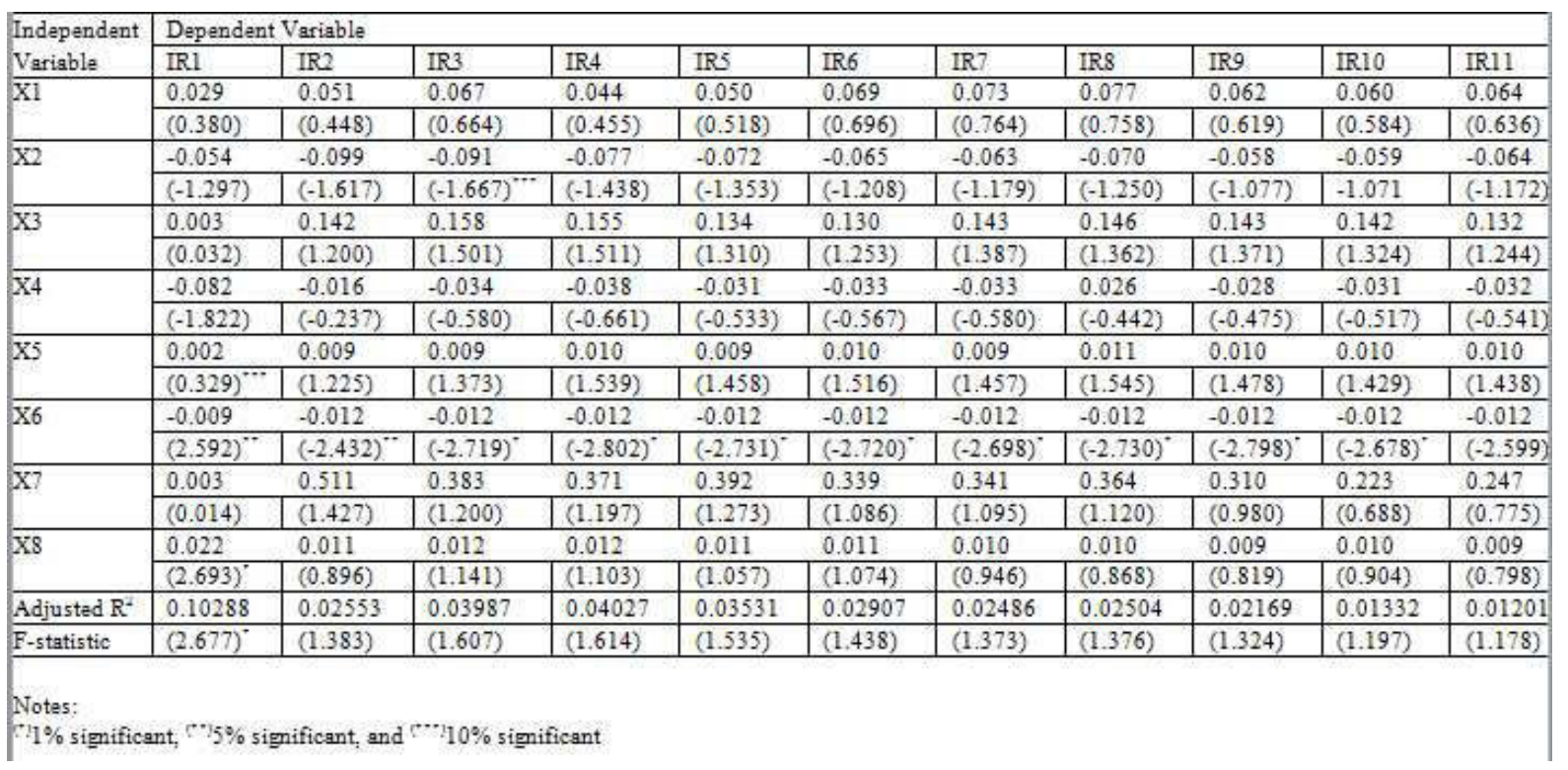

